ISSN 1982-8713

\title{
Materials of Eastern Origin Discovered in the Former Territory of the Roman Empire, with India and China in Focus: Examples of Direct and Indirect Interactions from an Archaeological Perspective.
}

Materiais de origem oriental descobertos no antigo território do Império Romano, com foco em Índia e China: Exemplos de interação direta e indireta de uma perspectiva arqueológica.

\author{
Krisztina Hoppál ${ }^{1}$ \\ ${ }^{1}$ Institute of East Asian Studies, Eötvös Loránd University. MTA-ELTE-SZTE Silk Road Research Group. \\ Supported by the ÚNKP-19-4 New National Excellence Program of the Ministry for Innovation and \\ Technology, Hungary and the János Bolyai Research Scholarship of the Hungarian Academy of Sciences. \\ E-mail: hoppalkriszti85@gmail.com.
}

Recebido em 10 de julho de 2020; Aceito em 17 de novembro de 2020.

DOI: $10.12957 /$ nearco.2020.57505

\begin{abstract}
The study on links between the Roman Empire and the East can be considered a popular yet complicated field of research posing several problems and questions. The role of archaeological data - particularly of objects from the East - is somewhat still less recognized compared to texts. Thus, the paper puts together a range of evidence of South Asian and Far Eastern origin discovered in provinces of the Roman Empire in order to illustrate the variety of materials and the different focus of interactions.
\end{abstract}

Keywords: Archaeology; Roman Empire; South Asia; China; cross-cultural interactions.

\section{Resumo}

O estudo de relações entre o Império Romano e o Oriente pode ser considerado popular, porém representa um complicado campo de estudos com diversos problemas e questões. O papel dos dados arqueológicos - especialmente os objetos do Oriente - é de certo modo ainda menos reconhecido comparado aos textos escritos. Sendo assim, este artigo reúne uma série de evidências oriundas do Sul da Ásia e do Extremo Oriente descobertas em províncias do Império Romano, objetivando ilustrar a variedade de materiais e os diferentes focos de interações.

Palavras-chave: Arqueologia; Império Romano; Sul da Ásia; China; Interações culturais.

Introduction

Studying Eastern contacts of the Roman Empire, particularly the Indo-Roman (Mediterranean-Indian Ocean) trade is a very expansive field of research, in which the vast 
NEARCD: Revista Eletrônica de Antiguidade

2020, Volume XII, Número II - ISSN IS8R2-8713

Núcleo de Estudas da Antiguidade - NEA

Universidade da Estada do Rio de Janeiro

ISSN 1982-8713

textual evidence (both Western and Eastern i.e. typically Chinese) has a pivotal role. ${ }^{1}$ At the same time, significance of archaeological testimony of these interactions regarding their type of material (genuine or raw), although the focus of contacts (direct or indirect) has less been articulated, and most studies were limited to the Indo-Roman data. Whereas further systematization of archaeological remains both from South Asia and beyond not only qualify the descriptions provided by written sources, but are also essential in order to build a more comprehensive database based on techno-stylistic categories, through which the different levels of interactions and cultural transfers between the various social groups of the Mediterranean, South Asia, Southeast Asia and China is able to be better understood, and also a more exhaustive sequence of cultural exchange could be set up. ${ }^{2}$

The primary aim of the paper is to (re-)introduce the most striking archaeological objects of Eastern origin - particularly from South and East Asia - focusing on their material and the directness of interactions, and thus, do highlight some new possibilities for further research. Thus, not a list of archaeological finds nor a comprehensive review will be given, but rather a range of evidence with great research potentials yet to be fulfilled.

\section{Direct interactions between the Roman Empire and the East: Materials from/through India}

Direct links can be considered a relatively active type of contacts, in which the place of arrival had already been determined at the point of departure, or at least some knowledge on the final destination of the sent objects existed as early as the departure. Existence of direct contacts can be seen particularly during the (early) Roman imperial period between the Mediterranean world and the East, with relative certainty as far as the Western coast of India, while frequency of direct contacts with the Eastern coasts is more debatable. ${ }^{3}$ Besides texts,

\footnotetext{
${ }^{1}$ Several great works mostly from a comprehensive historical and economic view have been published over the vast history of research. Some of the latest inter alia: McLaughlin 2016; Evers 2017; Cobb ed. 2019; Beaujard 2019; For an thorough review of Eastern commodities based on the vast textual evidence see: Parker 2002.

${ }^{2}$ A structure of techno-stylistic categories of Western objects discovered in South Asia, Southeast Asia and China along their possible integration into local repertoires has been built by Krisztina Hoppál, Bérénice Bellina and Laure Dussubieux. See: Hoppál et al. forthcoming

${ }^{3}$ E.g. E. Seland sees them quite infrequent, at the same time - as P. Beaujard has pointed out ", If the Roman presence in the East was really as "infrequent, or even exceptional" as Seland suggests (2007: 79), why then did the Periplus of the Erythraean Sea bother to list six places on the southeast coast of India" Seland 2007, 79-80; Beaujard 2019, 398. Interpretation of Arikamedu is particularly divisive. See e.g. Begley 1983; Seland 2007, 70; Dayalan 2019; Fauconnier 2012, 89-90. etc.
} 
NEARCD: Revista Eletrônica de Antiguidade 2020, Volume XII, Número II - ISSN IS8R2-8713

Núcleo de Estudas da Antiguidade - NEA

Universidade da Estada do Rio de Janeiro

ISSN 1982-8713

intensification in interactions between the Imperium (typically the Mediterranean world) and India during the last centuries BC can also be seen through a number of archaeological evidences discovered in regions of the Mediterranean, ${ }^{4}$ but the most glaring in the archaeological data is the period from the $2^{\text {nd }}-1^{\text {st }} B C$ followed by the $1^{\text {st }}$ century $A D$ peak. ${ }^{5}$

During this period both genuine objects of Eastern origin (isolated objects and collective finds) and raw materials can be discovered in several provinces of the Imperium. A very illustrative and well-known example of isolated objects is the Indian ivory figurine possibly part of a handle or furniture from Pompeii: ${ }^{6}$ Several finds of direct contacts - also known from textual evidence $^{7}$ - were discovered in Mediterranean port sites, among which Berenike ${ }^{8}$ and Quseir alQadim $^{9}$ in Egypt are the most notable examples. Rouletted Ware and Paddle-impressed Ware discovered at these sites are illustrating the existence of early links. ${ }^{10}$ The Tamil-Brahmi graffittos found in both Berenike and Quseir al-Qadim are also often cited examples of IndoMediterranean contacts, but the presence of any of these materials at port sites does not imply transfer of any kind. ${ }^{11}$ Excavations have revealed a wide range of East arrived perishable goods from both sites, such as the notable black pepper, rice, coconut, bamboo, teak etc. ${ }^{12}$ Among these examples, unquestionably remains of black pepper occur most often in archaeological data of the Imperium. ${ }^{13}$ The spice was found in relative abundance in both Berenike (e.g. 7.55 $\mathrm{kg}$ of black peppercorns from one single jar) ${ }^{14}$ and Quseir al-Qadim. ${ }^{15}$ Wide range of availability

\footnotetext{
${ }^{4}$ For early exchange of plants and other goods for consumption e.g.: Fuller 2011: 352-353. However, as M. Cobb has pointed out in case of some $3^{\text {rd }}-2^{\text {nd }}$ century BC textual references, It might be questioned whether these products were genuinely Indian (as we would understand it) or, in fact, derived from places like East Africa." Cobb 2019: 21. Pre-Roman evidences of interactions are more abundant in the South Arabian regions (see below), where ports also acted as intermediaries between India and Egypt. Cobb 2019: 20-21.

${ }^{5}$ E.g.: Cobb 2019.

${ }^{6}$ See Cimino ed.1994: 119-122; Berry 2007: 200; Evers 2017: 22-46. all with further bibliography.

${ }^{7}$ Most recognizably from the Periplus Maris Ertyhraei. See: Casson 1989.

${ }^{8}$ Sidebotham 2011.

${ }^{9}$ Peacock at al. eds. 2011.

${ }^{10}$ Tomber 2000; Tomber 2002, 27; Sidebotham 2011, 231; Schenk 2015.

${ }^{11}$ Moreover, as F. M. Asher has pointed out,, The evidence, in other words, supports only Indian trade by sea, not Indian traders at sea." Asher 2019, 158. The silver coin of King Rudrasena III of the Kshatrapas of western India issued in 362 from in Berenike's fifth-century church is obviously a much later example. Sidebotham 2011, 240.

12 See: Cappers 2006 and van der Veen 2011.

${ }^{13}$ For a detailed summary see e.g. Cobb 2018a.

${ }^{14}$ Cappers 1998, 289-330; Sidebotham 2011, 224-225.

${ }^{15}$ van der Veen 2011, 41.
} 
NEARCD: Revista Eletrônica de Antiguidade 2020, Volume XII, Número II - ISSN IS882-8713

Núcleo de Estudas da Antiguidade - NEA

Universidade da Estada do Rio de Janeiro

ISSN 1982-8713

and accessibility of pepper can not only be seen via textual references but also through epigraphical data, such as the wooden tablet from Vindolanda on purchasing pepper by a soldier - interestingly - not of a high rank stationed at the fort, ${ }^{16}$ and also on a Roman lead object found in Trier used as a label for appr. 2,6 kg pepper, ${ }^{17}$ or through a number of unintentional deposits of mostly smaller amounts of peppercorns ${ }^{18}$ from Roman Germany, France, Britain and Croatia. ${ }^{19}$ The case of piperatoria (suggested to be pepper shaker) is more controversial, phytolith analysis might confirm its function. ${ }^{20}$

Both spices, plants and cotton too, are examples of direct trade, the latter posing both opportunities and challenges as study of weaving patterns is necessary in order to differentiate Indian made fabrics from Mediterranean (Egypt) produced textiles. ${ }^{21}$ More easily identifiable, although $5^{\text {th }}$ century example are the resist-dye fragments from Berenike, ${ }^{22}$ to which a strikingly similar specimen was discovered in Karadong, Xinjiang from $3^{\text {rd }}$ century context..$^{23}$

\section{Indirect interactions between the Roman Empire and the East: Materials from further East}

In contrast of direct contacts, indirect contacts are nominally more passive, and a series of middlemen were involved in transferring the objects, and the final destination was most likely only determined by (one of) these mediators. These indirect links do not imply close interactions with the Mediterranean world/ Roman Empire. In the case of Eastern objects originating beyond South Asia, mostly indirect contacts can be assumed. Concomitantly, occasional ${ }^{24}$ direct visits to

\footnotetext{
${ }^{16}$ Bowman and Thomas 1994, 135-138.

17 Schwinden 1983, 22; Cappers 2006, 114; Cobb 2018a, 538.

${ }^{18}$ An example of noticeable amounts are the 52 peppercorns discovered in the harbor area of Straubing (Germany), and another one of 70 peppercorns at Cuijk (Netherlands) from a pit of $3^{\text {rd }}-4^{\text {th }}$ century dating. See: Küster 1995, 137; Cobb 2018a, 538; Heinrich 2017, 26; Aarts et al. 2017.

${ }^{19}$ For a summary: Cappers 2006, 117-119; Livarda 2011, 156-160; Robinson and Rowan 2015, 106-109.

${ }^{20}$ See McDuff 2019, 25-26.

${ }^{21}$ See e.g.: J. P. Wild and F. Wild 2005.

22 Sidebotham 2011, 243; J. P.Wild and F. Wild 2014, 223-224. Other resist-dyed fragments of Indian origin from the same site: J. P. Wild and F. Wild 2005, 15-16.

${ }^{23}$ Desrosiers and Debabain-Francfort and Idriss 2001; Desrosiers and Debabain-Francfort 2016.

24 The Liang shu indicates more often visits from the West: ,,[...]其國人行賈, 往往至扶南、日南、交 趾, 其南徼諸國人少有到大秦者。Their people [from Daqin accepted to refer to the Roman Empire] are traders and often visit Funan [Cambodia, the southern part of Laos and Vietnam, and the southeastern part of Thailand] and Rinan [Its seat of government is located where the Quảng Trị and Cam Lộ rivers meet in the present Bình Trị Thiên Province of Vietnam] and Jiaozhi [its seat of government is located to the northwest of Hanoi.], but people of various countries beyond our southern border rarely reach Da Qin." Original and translation: Yu 2013, 119-120.
} 
NEARCD: Revista Eletrônica de Antiguidade

2020, Volume XII, Número II - ISSN IS8R2-8713

Núcleo de Estudas da Antiguidade - NEA

Universidade do Estada do Rio de Janeiro

ISSN 1982-8713

(but very rarely from ${ }^{25}$ ) these areas might have taken place, as both Chinese and Western texts suggest, such as Andun 安敦's envoy to China mentioned by Chinese standard histories, ${ }^{26}$ or the Macedonian merchant, Maes Titianus' (or his agents'), travel to the East cited by Ptolemy, ${ }^{27}$ although none can be seen via archaeological evidence. ${ }^{28}$ Moreover, these references, despite their interest per se, do not provide information on their possible local consequences. Thus, there is no evidence that they generated transfers of any kind.

An exceptional example of isolated finds is the nephrite scabbard slide of Chinese origin from Čatalka, Stara Zagora region, Bulgaria. The object was placed into the richly furnished burial of a cataphractarius, a heavily armoured type of Roman cavalry, dated to the end of the $1^{\text {st }}$ century $A D$-beginning of the $2^{\text {nd }}$ century $A D .{ }^{29}$ The nephrite object was placed on a richly decorated iron sword interpreted as Sarmatian type and served as a belt loop at the middle of the sheath. The yellowish-greenish stone features two animals ${ }^{30}$ carved on its surface, the raw material of the motif slide coming from the Kunlun Mountain 昆仑山 and could be extracted all along the Tarim river, Xinjiang, China. ${ }^{31}$ The nephrite scabbard slide differs both stylistically and materially from the rest of the ornaments, and it is dated to the Han Dynasty. Identification of the owner is also problematic; he seems to be a high-ranking Thracian officer of the Roman army buried (partly) with Sarmatian artefacts (trophies or gifts?). ${ }^{32}$ Notwithstanding the nephrite slide's importance it does not confirm contacts between China and the Imperium, but does offer

The Liang shu, another piece of the standard histories, is dated to the $7^{\text {th }}$ century and refers to the period

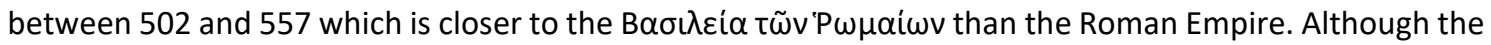
work partly summarizes earlier sources, unlike other historiographies it does not give a separate Daqin chapter but integrates these passages into the section of Tianzhu 天䇥 i.e. India. Among information repeated in Tang period, a number of new materials can also be detected. For reliability see: Hoppál 2019.

${ }^{25}$ Florus' account on the embassy sent by the Seres i.e. Silk people to Augustus' court (Florus Epit., II,34) is most likely one of the author's typical hyperbolysms. E.g.: Coèdes 1910, XII; with other explanation: Malinowski 2012, 21. Moreover, identifying the Seres with Chinese people is very problematic, as the well-known term was rather used as a vague ethnonym than a well-defined title designating a state. See: Hoppál 2015 and 2018.

${ }^{26}$ E.g. in the Hou Han shu 後漢書, see e.g.: Hoppál 2011 and 2019.

27 Ptolemaios Geog., I, 11,1-7. See e.g. Dan 2013; Tupikova et al. 2015 with further bibliography.

${ }^{28}$ At the same time, recent results of bioarchaeology might provide more evidence of Eastern arrivals. See below.

${ }^{29}$ Bujukliev 1986; Werner 1994, 269-73.

${ }^{30}$ Possibly dragons, however several other identifications have been used. For a summary: Gonthier et al. 2014, 8.

${ }^{31}$ Werner 1994, 274-278; Gonthier et al. 2014, 6. Details on its archaeological distribution and analogies are also included.

${ }^{32}$ Werner 1994, 272-273, 281-282; Gonthier et al. 2014, 7; 
NEARCD: Revista Eletrônica de Antiguidade 2020, Volume XII, Número II - ISSN 1982-8713

Núcleo de Estudas da Antiguidade - NEA

Universidade da Estada do Rio de Janeiro

ISSN 1982-8713

an understanding on links between China and the Sarmatians, all the more so since objects of Chinese origin are not rare in Sarmatian assemblages. ${ }^{33}$ At the same time, it might be worth an in depth study of the possible techno-stylistic connections between a Han Dynasty jade slide from a Chinese collection (CZ.14) and its analogies made of ivory and bone from Khisfine, Syria (S.1-2), Vimose, Fyen, Denmark (E.2), Novae, Bulgaria (E.35) and Intercisa, Hungary (previously interpreted as hair ornament) ${ }^{34}$ since those are all cited as being 'nearly identical' in the monumental work by W. Trousdale. ${ }^{35}$ Moreover, the Novae slide has even been referred to as an imitation of the previously mentioned Chinese piece by É. Gonthier et al. ${ }^{36}$

Other, previously often cited yet very dubious materials of Far Eastern origin are bronze ritual vessels (said to be) discovered in the former territory of the Imperium. In 1885 a Chinese hu vessel 青铜壶was presented to the British Museum by Henry Willett, and was claimed to be unearthed in the medieval Dane John Canterbury. ${ }^{37}$ Although the object has its analogies dated to the late Spring and Autumn-early Warring States period ( $6^{\text {th }}-5^{\text {th }}$ century BC), L. Ashton and B. Gray in their work entitled Chinese Art raised the possibility of Han dating (206/202 BC-220 AD). Furthermore, Ashton and Gray theorized a wealthy Roman as the possible owner of the vessel, ${ }^{38}$ although both the context and reliability of the finding is questionable as it is very unlikely that the object could be an ancient or medieval arrival. ${ }^{39}$ Another Chinese $h u$ vessel from the Hellström Collection has a similarly doubtful background. It was said to be discovered in the gardens of Mons Esquilinus, and was dated to the Han Dynasty by B. Vessberg. Vessberg has connected it to a wealthy Roman collection ${ }^{40}$ similar to the one in Cicero's In Verrem. ${ }^{41} \mathrm{~A}$ third bronze ritual vessel, a fragmentary gu解, now in the Museo Nazionale d'Arte Orientale was said to be discovered among the remains of a sunken Roman cargo ship near Ostia in $1941 .{ }^{42}$ The uncertain context of these objects make any attempt for further interpretation somewhat

\footnotetext{
33 E.g.: Werner 1994, 274; Simonenko 2001; Treister 2018.

${ }^{34}$ Sági 1954, 72, plate XX 3.

35 Trousdale 1975, p. 221 for the Vimose piece; p. 229 for the Novae find; p. 236-237 for the Khisfine pieces, p. for the Chinese jade slide p. 217.

${ }^{36}$ Gonthier et al. 2014, 11.

37 Jones 1990, 94-95. entry 88.

${ }^{38}$ Ashton - Gray 1953. 58. Also: Whitehouse 1972, 66.

39 Jones 1990, 95.

${ }^{40}$ Vessberg 1937.

${ }^{41}$ Cicero, In Verrem II, 2, 19; IV, 23,44;59.

42 Petech 1950; Li and Allan 1995, entry 28; Lawton 1997, 167.
} 
NEARCD: Revista Eletrônica de Antiguidade 2020, Volume XII, Número II - ISSN 1982-8713

Núcleo de Estudas da Antiguidade - NEA

Universidade da Estada do Rio de Janeiro

ISSN 1982-8713

difficult, however it is possible they are all modern arrivals rather than isolated finds of SinoRoman (indirect) connections.

Other materials of Far Eastern origin demonstrate greater potential for further research, as well as several complications. ${ }^{43}$ To wit, one of the most notorious examples is silk - often being connected to China regardless its true origin. However, due to their highly perishable nature of it as a material, apparent pieces of China-produced textiles are very rare in ancient textile assemblages of the Roman Empire. Therefore, it is not cognizant that the remains of jin 錦textiles discovered in the ancient caravan city of Palmyra are highly recognized in archaeological literature. ${ }^{44}$ Very illustrative examples were discovered in the merchant, Kitot's tower tomb dated to the mid- $1^{\text {st }}$ century $A D$, which contained two exceptional fragments of $j$ in fabrics with Chinese characters. ${ }^{45}$

In Palmyra, locally made textiles featuring elements of Chinese silk motifs and patterns, mostly made of local raw material by local techniques but in Eastern style can also be observed. A very striking example is the indigo dyed woollen fabric of fine gauzelike quality decorated with lozenge pattern and filled with double piles (inv.no.: PAM K 7.1-3) from again Kitot's tower tomb. In this case the decoration was not executed by tapestry technique but invowen with an additional thread. ${ }^{46}$ Yet again, such examples do not conclusively imply necessarily sustained or close interactions, nor real transfer, despite the fact that inspiration on weaving technique from Han damasks might be detected, because the ",technology itself traces back to western roots" ${ }^{47}$. It is also interesting to note, that an example of adaptation of Western elements into local raw material by using local techniques can be detected on a Chinese polychrome silk textile of typical Chinese technique decorated with grape-picking human figures, these Western artistic elements, discovered - surprisingly - in Palmyra. At the same time, as M. Żuchowska has concluded, "since this scene has no parallels in the Chinese art and craft, it must have been observed on a foreign product and then copied or imitated in the jin pattern." ${ }^{48}$ )

\footnotetext{
${ }^{43}$ E.g.: Hildebrandt $2017 \mathrm{a}$ and $\mathrm{b}$.

${ }^{44}$ See Hoppál: 2015: 241-245; Żuchowska 2013: 133-154; Żuchowska 2015: 143-162. All with further bibliography.

${ }^{45}$ Schmidt-Colinet and Stauffer and Al-As'ad 2000: 142; Falkenhausen 2000: 66-70, 74; Hoppál 2015: 241245.

${ }^{46}$ Stauffer 1996: 427; Schmidt-Colinet and Stauffer and al-As'ad 2000: Kat.54, 113-114, Abb.51, 74, TAF 68c-69a.

${ }^{47}$ Stauffer 1996, 427

${ }^{48}$ In detail: Żuchowska 2015.
} 
NEARCD: Revista Eletrônica de Antiguidade 2020, Volume XII, Número II - ISSN IS8R2-8713

Núcleo de Estudas da Antiguidade - NEA

Universidade da Estada do Rio de Janeiro

ISSN 1982-8713

As it is well recorded in texts and archaeological data, silk threads were also used (and re-used) as raw materials, and both tabbies and yarns could be imported. At the same, time it is crucial to take into account, that two kinds of silk were known and used in the Roman Empire: domestic/cultivated/genuine silk and wild silk. ${ }^{49}$ The former is generally connected to the species of Bombyx mori, while the latter comes from the various species of wild moth. ${ }^{50}$ These different kinds of silk show certain differences in their characteristics. Controlled cultivation of Bombyx mori silk is generally attributed to China, although from the $3^{\text {rd }}$ century local sericulture also started in Xinjiang. ${ }^{51}$ Wild species of silk moths were relatively widely spread in Antiquity, such as Middle and East Asia and the Mediterranean area. ${ }^{52}$ In order to identify the raw material of which a fabric was made (thus differentiate Bombyx mori silk from other silk types) a detailed examination conducted by experts specialized in ancient textile research is needed, which is often achieved by using methods of natural science. At the same time, because of the preservation and condition of many of the silk remains discovered in the former territory of the Roman Empire, as such the analyses cannot be carried out. Palmyra is again a positive example in this regard. For instance, two examples of damask made of fine mulberry silk, which are considered as products made in Syria using imported Chinese yarn were found. ${ }^{53}$ Examples of wild silks made of Antharaea species cocoons, which are indigenous in Southern China and South Asia were also discovered. ${ }^{54}$

Besides significant trading nodes, evidences of using raw or recycled silk of Eastern origin were uncovered in both significant and smaller sites of the Roman Empire. Such as Rome, where scanning electron microscope was applied to identify Bombyx mori silk fibre in case of a fabric discovered in the gallery 28 of the Catacombs beneath Sant'Agnese, Via Nomentana $351 .{ }^{55}$ Because of the lack of such analysis, fibre distinctions (i.e. being Chinese or wild) in case of the

\footnotetext{
${ }^{49}$ The question of sea-silk production in Antiquity is rather problematic. Hoppál 2015, 238-239.

${ }^{50}$ Zhao 2017, 100.

51 Zhao 2017: 102.

52 The famous story by Procopius about how Christian monks had smuggled silk worms to the court of emperor Justinian in the $6^{\text {th }}$ century meaning the start of Byzantine sericulture has still not been convincingly challenged by archaeological materials. Procopius, De Bellis, IV. (VIII.) 17.1-7. See also: Hildebrandt 2017a: xi.

${ }^{53}$ One is dated to the late $1^{\text {st }}$, the other is to the early $2^{\text {nd }}$ century AD. Schmidt-Colinet and Stauffer and al-As'ad 2000: 53-55; Kat. 319, 159; Kat. 453, 178; Żuchowska 2016: 147.

${ }^{54}$ Żuchowska 2016:147. E.g. Kat. 313 of possibly Indian origin dated to late $1^{\text {st }}$ century AD. Schmidt-Colinet and Stauffer and al-As'ad 2000:157.

55 See: Mitschke and Paetz gen Schieck 2012:122-123.
} 
NEARCD: Revista Eletrônica de Antiguidade 2020, Volume XII, Número II - ISSN 1982-8713

Núcleo de Estudas da Antiguidade - NEA

Universidade da Estada do Rio de Janeiro

ISSN 1982-8713

textile fragments from sites in Pannonia are less certain. However, those typically $4^{\text {th }}$ century provincial burials show the relative commonness of silk materials, and present their integration into the context of Roman textile repertoire without any sense of their eastern origin. ${ }^{56}$ These examples of Far Eastern raw materials or recycled raw materials by local techniques and in local/regional style indicate indirect contacts and no social interactions.

\section{Potentials for further research}

Other raw materials, particularly precious and semi-precious stones provide numerous and promising possibilities of studying interactions between the Mediterranean world and South Asia (and beyond). Such as in the case of red gemstones identified mostly as garnets suggest the existence of sustained contacts between the Mediterranean world (and other parts of Europe) and southern South Asia. These gemstones were relatively widespread in Europe during the migration period $\left(5^{\text {th }}-6^{\text {th }}\right.$ century $\left.A D\right)$, typically connected to Germanic people, used as inlay decoration of fine metalwork, often by the application of cloisonné technique. The comparative analysis of the mineral inclusions and the concentration of the major constituents pointed out that certain types originated from alluvial deposits of South India and Sri Lanka. ${ }^{57}$ Moreover, excavations of the site Diana in Alexandria dated to the late Antiquity revealed flourishing lapidary activity identified as a possible link between the production and commercial chain of such cloisonné jewellery. ${ }^{58}$ The accessibility of the material is clearly illustrated by the Carpathian Basin examples, where for instance loose, i.e. unmounted pieces of garnet of possibly southern Indian origin were discovered as sole remains in a robbed grave of a $5^{\text {th }}$ century AD cemetery in Hajdúnánás (Hajdúnánás-Fürj-Halom-dúlő site, Hungary). ${ }^{59}$

Other stones of Eastern origin might also provide further potentials. Such as jade coming from mineral sources of Burma, China, or Kashmir and Siberia; however only very small number of the material are known from Roman context to date. A recently published example is an

\footnotetext{
56 Hoppál 2020.

${ }^{57}$ For such comparative analyses e.g.: Calligaro et al. 2002; Périn et al. 2007; Calligaro et al 2008; 2010; Gilg et al.2010.

58 Rifa- Abou El Nil and Calligaro 2020.

${ }^{59}$ Horváth and Bendő 2011.
} 
NEARCD: Revista Eletrônica de Antiguidade 2020, Volume XII, Número II - ISSN 1982-8713

Núcleo de Estudas da Antiguidade - NEA

Universidade da Estada do Rio de Janeiro

ISSN 1982-8713

unworked piece excavated in Quesir al-Qadim (L139 from Tr. 2B 2304), and another small piece is known from the ancient quarry of the Mons Claudianus (Egypt). ${ }^{60}$

Studying beads of Eastern origin has great research potentials as well, such as the stupa beads associated with Buddhism. ${ }^{61}$ These beads, along with other 'Indo-Pacific beads', have been discovered in relatively great quantity at Marsa Nakari, Egypt from $4^{\text {th }}$ century AD context, not only illustrating connections with Sri Lanka, but - as J. Then-Obłuska highlighted - also raising the question of potential Sri Lankan residents at the site. ${ }^{62}$ However, further comparative research would be needed to confirm this theory. Besides Roman period sites, beads of IndoPacific origin have been identified in a Merovingian grave at Saint-Laurent-des-Hommes (Dordogne), France, also illustrating the possibility of sustained contacts with South Asia. ${ }^{63}$

Mitochondrial genomes and isotopes also provide significant research opportunities as those might reveal relationships and geographic origin of non-local individuals or groups. Such as in case of the $1^{\text {st }}-4^{\text {th }}$ century Roman cemetery at the imperial estate of Vagnari, Italy. ${ }^{64}$ Preliminary DNA by T. Prowse et al. had already identified an individual (F37) of East Asian affiliation. ${ }^{65}$ More recent analyses confirmed the above results and also showed that the ancestors of an adult male (F34) - who himself was most likely born at or around Vagnari - and also the 45-49 years old female (F37) originated from Eastern Eurasia (possibly Asia proper) sometime prior to the 1 st century AD. These two individuals might also share the same maternal ancestor. ${ }^{66}$ Both were excavated from Trench 9 in close proximity to one another. The skeletons were placed in a pit, covered by tegulae, which considered the most common type of graves for ordinary individuals (so-called alla cappuccina) during this period. The burials had WestSouthwest orientation and are dated to the $3^{\text {rd }}$ century AD. Although other graves mostly contained local ware, the male was buried with an African red slip dish of Hayes form 16, and the women with an African cooking pot lid of Hayes form 196B with a nail. ${ }^{67}$ African imports were not rare among grave goods of the cemetery which ,suggests that the community at

\footnotetext{
60 Peacock 2011, 122.

${ }^{61}$ Francis 2002, 137-138.

62 Then-Obłuska 2018, 278-279, with other examples of Asian beads and further bibliography.

63 Poulain et al., 2013, 78.

${ }^{64}$ Small et al. 2007; Brent and Prowse 2014.

65 Prowse et al. 2010, 186-187, 189-191.

${ }^{66}$ Emery et al. 2018, 204-206.

${ }^{67}$ Small et al. 2007, 127-128, 136.
} 
NEARCD: Revista Eletrônica de Antiguidade 2020, Volume XII, Número II - ISSN 1982-8713

Núcleo de Estudas da Antiguidade - NEA

Universidade do Estada do Rio de Janeiro

ISSN 1982-8713

Vagnari was living at a reasonable level of subsistence, in spite of the physically demanding lifestyle [...]." ${ }^{\prime \prime 8}$ Besides the African ware, the man also had an iron cutting tool at the head, fragments of a sandy grey casserole with a nail under the pot, ${ }^{69}$ and several small iron nails of a hobnail shoe at the feet. ${ }^{70}$ Exact social status of the two individuals is unknown as it is not possible to distinguish between slaves, freedmen or tenants at Vagnari based on current archaeological evidence, ${ }^{71}$ but they were buried similarly to other individuals of the cemetery.

Skeletal morphology applied on the $2^{\text {nd }}-4^{\text {th }}$ century AD cemetery of Southwark, London ${ }^{72}$ also revealed that two individuals, a 18-25 and a 26-35 years old male had possible Asian ancestry. The younger - whose grave is dated to the $2^{\text {nd }}$ century $A D$ - also had a diastema between his first maxillary incisors, and both him, both the older - whose grave is dated to the $4^{\text {th }}$ century AD - shared the same diet as others from the cemetery: consuming local food. ${ }^{73}$ It has also been suggested that all non-local individuals , had lived in Londinium for several years before their death, but had migrated there after the age of enamel formation." ${ }^{74}$ At the same time, the above bioarchaeological results are needed to be perceived cautiously as the applied method is a statistical modelling which was based on modern populations. ${ }^{75}$

Explaining the existence of these individuals in Roman cemeteries is still problematic, it is unclear whether the move of their ancestors was forced or willingly initiated, ${ }^{76}$ and those people were enslaved, or involved in long-distance exchange, or were mere travellers. What can be inferred from the Vagnari graves is that the two individuals with non-local ancestors were buried according to local customs along with local grave goods, which might reflect on how they were received by the local community.

Besides studying raw materials, beads and skeletal remains of Eastern origin from Roman and post-Roman context, integration of the rich corpus of evidence from the southern parts of Arabia (particularly Oman and Yemen) and Eastern Africa would also provide new

\footnotetext{
${ }^{68}$ Small et al. 2007, 138. For skeletal pathology of the two individuals: Small et al. 2007, 152, 159.

69 These pots associated with iron nails might have been used for magical purpose. Small et al. 2007, 142, 145.

${ }^{70}$ Small et al. 2007, 139, 141, 144, 146-147, 163-164, 173-174.

${ }^{71}$ Prowse et al. 2010, 191.

72 Ridgeway et al. 2013.

73 Redfern et al. 2016, 15-16.

${ }^{74}$ Redfern et al. 2016, 19.

${ }^{75}$ Redfern et al. 2016, 19.

${ }^{76}$ Emery et al. 2018, 205.
} 
NEARCD: Revista Eletrônica de Antiguidade

2020, Volume XII, Número II - ISSN IS8R2-8713

Núcleo de Estudas da Antiguidade - NEA

Universidade da Estada do Rio de Janeiro

ISSN 1982-8713

perspectives. In addition to well-known and often cited examples, such as the Indian statuette from Khor Rori area (in Oman) ${ }^{77}$ or the rich epigraphical evidence from Cave Hoq on Socotra Island (today part of Yemen), ${ }^{78}$ significance of ceramics of Indian origin (some indicating longexisting interactions) $)^{79}$ and possible forms of Indian visual solutions and artistic elements on Arabian Gulf materials ${ }^{80}$ have also been articulated. Research projects aiming to integrate the rich body of material evidence of these vast regions ${ }^{81}$ have already achieved promising results.

A methodological approach focusing on style and technique could also be formulated in order to systematize Eastern material in the West - as it has already been performed in case of Western material discovered in the East. ${ }^{82}$ This not only allows to have a better distinction of certain materials, but also gives the opportunity to define certain degrees and qualities of interactions and to examine the possible manifestations of (real) transfers.

Moreover, building a comparative corpus including all materials both from East and West would be a significant step towards achieving a more complex understanding of these ancient intertwined networks operating between these key regions. Reception studies might also provide a new insight of research. Comparing the differences and similarities between the reception of non-local artefacts in various local communities might reveal how and why certain non-local objects had been (re)interpreted by local networks. Although several research problems narrow the possibility of interpretations, following the social life of certain non-local objects would still provide significant elements towards broadening our comprehension, such as in the case of (Chinese) silk which was differently received in certain times, which from being a symbol of abhorrent extravagance incrementally became the appropriate garment of imperial

\footnotetext{
77 Goetz 1963. Another one was found by the Italian Archaeological Missionin Oman. See: Autiero 2018, 409, note 4.

78 Strauch 2012.

79 Schenk and Pavan 2012; Schenk 2015; Reddy 2015; Reddy 2016.

${ }^{80}$ Autiero 2018. K. Evers mentions, 'Indianising' influence on Roman ornamental furniture and artwork" based on $2^{\text {nd }}$ century $A D$ marble heads wearing their hair in a topknot, however further research would be needed defining to what degree those portrays could be seen as potential forms of cultural 'influence', or those were rather ways of visual codes representing India? See: Evers 2017, 40; On this problem with more examples on 'Roman representations of India': Parker 2008, 121-143. On the marble heads with topknot also: Schneider 1986, 156, 177-178, 216. Cimino ed. 1994, 126-128.

${ }^{81}$ Such as the research project of the Leiden University entitled ' Routes of Exchange, Roots of Connectivity The archaeology of Afro-Eurasian networks across land and sea (1st millennium CE)' https://www.universiteitleiden.nl/en/research/research-projects/archaeology/early-networks-of-theafro-eurasian-silk-roads\#tab-1

82 See: Hoppál et al. forthcoming
} 
NEARCD: Revista Eletrônica de Antiguidade

2020, Volume XII, Número II - ISSN IS8R2-8713

Núcleo de Estudas da Antiguidade - NEA

Universidade da Estada do Rio de Janeiro

ISSN 1982-8713

and clerical magistraturae in Late Antiquity. ${ }^{83}$ Or in case of glass vessels of Mediterranean origin, which were differently received in certain regions, i.e. being luxurious trade-connected commodity or hardly attainable genuine prestige object. ${ }^{84}$

\section{Conclusion}

Earliest links between the (primary) Mediterranean world and typically northern South Asia ${ }^{85}$ existed long before the Roman era, and were principally indirect and land route based, however archaeological testimony of these early contacts is more recognized in the East. ${ }^{86}$ Land as well as Indian Ocean exchange increased during the $3^{\text {rd }}-2^{\text {nd }}$ century $B C$, and reached its peak during the $1^{\text {st }}$ century $A D$ up until the $2^{\text {nd }}-3^{\text {rd }}$ century $A D,{ }^{87}$ resulting in an accumulation of both South (East) Asian and Far Eastern genuine objects, raw materials, and even imitations/adoptions/adaptations (e.g. the Palmyrene textiles featuring elements of Chinese silk motifs and patterns). During this period the first sustained and close links with Eastern(-ised) groups might be inferred. Information on later periods are less apparent. The $3^{\text {rd }}$ century AD can be seen as a period of recession followed by a reassessment of routes and networks, by which Sri Lanka and the southern regions of the Indian Subcontinent enjoyed greater importance, ${ }^{88}$ while between the $5^{\text {th }}$ and $8^{\text {th }}$ centuries land routes also reached their apex. ${ }^{89}$

Question of intermediaries has also been addressed in several studies, among which role of Nabateans etc. has already been pronounced. ${ }^{90}$ However, a better comprehension on mediators

\footnotetext{
${ }^{83}$ Hoppál 2020, 200.

${ }^{84}$ In case of China and Thailand see: Hoppál forthcoming

85 The question of when and where Chinese silk was first known in Europe is rather problematic, as authenticity of earlier and often cited examples have been questioned: Bender Jørgensen 2013. For a detailed summary with further bibliography: Hildebrandt 2017a. Glass analyses might also add further insights to the early West-East connections, such as in case of glass eye beads from Tomb Marquis Yi of the Warring States period. According to the XRF and Micro-Raman Spectrometry results, most of the analysed 46 beads belonged to the typical soda-lime-silicate glasses with low contents of $\mathrm{MgO}$ and $\mathrm{K} 2 \mathrm{O}$. The evidence from these analysed glasses found in China also suggest that these possible early contacts between China and the West might have been mainly land route based. See e.g. Zhao et al. 2014.

${ }^{86}$ For some objects of western origin see e.g.: Bopearachchi 2017, 17; Kilani 2017, 93-94. For a summary: Hoppál et al. forthcoming

${ }^{87}$ E.g. Cobb 2018b, 287.

${ }^{88}$ Beaujard 2019, 456. At the same time, R. McLaughlin describes a significant recovery in Rome's Eastern commerce" by the second half of the $3^{\text {rd }}$ century. McLaughlin 2010, 137-138.

${ }^{89}$ For a summary see e.g. de la Vaissière 2014, 104.

${ }^{90}$ Inter alia: McLaughlin 2010, 61-81, 95-97, 104-106, McLaughlin 2014, 50-58, Sidebotham 2011, 209212.
} 
NEARCD: Revista Eletrônica de Antiguidade 2020, Volume XII, Número II - ISSN IS8R2-8713

Núcleo de Estudas da Antiguidade - NEA

Universidade da Estada do Rio de Janeiro

ISSN 1982-8713

operating along maritime and terrestrial routes still requires further research, such as in case of Sarmatians, whose role has less been recognized. ${ }^{91}$ Presence of Westernised groups (particularly artisans) might be seen in some cases in the East, particularly northern South Asia (such as Barikot and Charsada ${ }^{92}$ or Bara, ${ }^{93}$ Pakistan), however it still needs to be analysed whether similar trend i.e. Easternised groups operating in the Imperium could be detected. Indian presence in the desert regions has already been articulated, ${ }^{94}$ but visualizing permanent residence of Indian groups in Mediterranean port regions (or further West) is more debatable. ${ }^{95}$ As it was introduced above, bioarchaeological analyses might also reveal certain individuals (possibly even groups) with Eastern affiliations, but detecting their possible identity and social role would require further research.

\section{References}

Acknowledgement: The author is very grateful to Dr. Strobe Driver for reviewing the paper from another academic perspective.

AARTS, J. \& CAPPERS, R.; HABERMEHL, D.; KEMPKENS, J.; KUBIAKMARTENS, L.; LANGE, S.; VAN RENSWOUDE, J.; VAN KERCKHOVE, J.; ZIMMERMAN, H. "De Romeinse muntschat", in D.S. HABERMEHL and J. VAN RENSWOUDE (red.), Duizenden jaren wonen op een rivierduin. Archeologisch onderzoek naar sporen van nederzettingsactiviteit tussen het Mesolithicum en de Nieuwe Tijd te Cuijk-De Nielt (= Nederlandse Archeologische Rapporten 44), Amersfoort, 2017, p. 479-515.

ASHER, F. M., "India abroad Evidence for ancient Indian maritime activity", in: M. COBB (ed.), The Indian Ocean Trade in Antiquity: Political, Cultural, and Economic Impacts, London and New York, 2018, p. 157-168.

ASHTON, L. and GRAY, B., Chinese Art, London, 1953.

\footnotetext{
${ }^{91}$ For Sarmatian's role in the northern Silk Road see e.g.: Hanus 2015.

92 Where imported molds and possibly even presence of Hellenistic itinerant craftsmen might be hypothesized see: Callieri 1995, 300. Also: Gosh 2012.

${ }_{93}$ Where possibly imported glassworkers with Western background might also be hypothesized operating mostly during the $1^{\text {st }}$ century AD. See: Lankton et al. 2015.

${ }^{94}$ E.g. Asher 2019, 158-159; Evers 2017, 124-126.

95 For this e.g.: Asher 2019, 158; For a collection of data: Salomon 1991; A Greek dedication to Pan by Sophon, the ,Indian' found in Egypt might be a possible evidence for a resident settler in the West. On this see e.g.: Von Lieven 2018, 66-67. However, problems of such 'ethnic reading' has also been raised, so much the more as the term ivઠós has also been interpreted as an occupation, i.e. elephant driver. See e.g. Mairs 2013, 174-182.
} 
NEARCD: Revista Eletrônica de Antiguidade 2020, Volume XII, Número II - ISSN 1982-8713

Núcleo de Estudas da Antiguidade - NEA

Universidade da Estada do Rio de Janeiro

ISSN 1982-8713

AUTIERO, S., "Foreign Iconographic Elements in South Arabian Art: the Indian Contribution", in: D. J. DE FALCO (ed.), Stories of Globalisation: The Red Sea and the Persian Gulf from Late Prehistory to Early Modernity Selected Papers of Red Sea Project VII, Leiden, 2018, p. 408-444.

BEAUJARD, P. The Worlds of the Indian Ocean: A Global History (Volume 1), Cambridge, 2019.

BEGLEY, V., "Arikamedu Reconsidered", American Journal of Archaeology 87/44, 1983, p. 461481.

BENDER JØRGENSEN, L., “The question of prehistoric silks in Europe” Antiquity 87/336, 2013, p. 581-588.

BERRY, J., The Complete Pompeii, London, 2007.

BOPEARACHCHI, O., "Achaemenids and Mauryans: Emergence of Coins and Plastic Arts in India", in A. PATeL, T. DARYAeE (ed.), India and Iran in the Longue Durée, California, 2017, p. 15-48.

BOWMAN, A. K. and THOMAS, J. The Vindolanda writing-tablets (Tabulae Vindolandenses II), Dorchester, 1994.

BRENT, L. and PROWSE, T. "Grave goods, burial practices and patterns of distribution in the Vagnari cemetery", in A. M SMALL (ed.), Beyond Vagnari: New Themes in the Study of Roman South Italy, Bari, 2014, p.99-110

BUJUKLIEV, К. Х. БУюклиЕВ, “Тракийският могилен некропол при Чаталка, Старозагорски окръг. The Thracian Tomb near Čatalka, Stara Zagora region", Разкопки и проучвания. Кн. [Excavations and Research.], XVI, София Sofia 1986.

CALLIERI, P., "The North-West of the Indian subcontinent in the Indo-Greek period. The archaeological evidence", in A. INVERNIZZI (ed.), In the Land of the Gryphons: papers on Central Asian archaeology in antiquity, Florence, 1995, p. 293-308.

CALLIGARO, T. \& COLINART, S.; POIROT, J.; SUDRES, C. "Combined external-beam PIXE and $\mu$ Raman characterisation of garnets used in Merovingian jewellery", Nuclear Instruments and Methods in Physics Research Section B: Beam Interactions with Materials and Atoms 189, 2002, p. 320-327.

CAlligaro, T. \& PERIN, P.; VAllet, F.; POIROT, J. "Contribution à l'étude des grenats mérovingiens (Basilique de Saint-Denis et autres collections du musée d'Archéologie nationale, diverses collections publiques et objets de fouilles récentes)", Antiquités Nationales 38, 2008, p. 111-144.

CALLIGARO, T. \& PERIN, P. ; SUDRES, C. "À propos du « trésor de grenats de Carthage ", attribué à l'époque vandale", Antiquités Nationales 40, 2010, p. 155-165. 
NEARCD: Revista Eletrônica de Antiguidade 2020, Volume XII, Número II - ISSN 1982-8713

Núcleo de Estudas da Antiguidade - NEA

Universidade do Estada do Rio de Janeiro

ISSN 1982-8713

CAPPERS, R. T. J. "Archaeobotanical remains", in S. SIDEBothAM and W.Z. WendRICH (eds), Berenike 1996, preliminary report of the excavations at Berenike (Egyptian Red Sea coast) and the survey of the Eastern Desert, Leiden, p. 289-320.

CAPPERS, R. T. J. Roman Foodprints at Berenike: Archaeobotanical Evidence of Subsistance and Trade in the Eastern Desert of Egypt, Los Angeles, 2006.

CASSON, L. The Periplus Maris Erythraei: Text with Introduction, Translation, and Commentary, New Jersey, 1989.

CIMINO, R. M. ed., Ancient Rome and India. Commercial and Cultural Contacts Between the Roman World and India, New Delhi, 1994.

COBB, M. A. "Black Pepper Consumption in the Roman Empire", Journal of the Economic and Social History of the Orient, 61/4, 2018a, p. 519-559.

COBB, M. A., Rome and the Indian Ocean Trade from Augustus to the Early Third Century CE, Leiden, 2018b.

COBB, M. A. ed., The Indian Ocean Trade in Antiquity: Political, Cultural, and Economic Impacts, London; New York, 2019a.

COBB, M. A., "From the Ptolemies to Augustus Mediterranean integration into the Indian Ocean trade", in M. A. CoBB ed., The Indian Ocean Trade in Antiquity: Political, Cultural, and Economic Impacts, London; New York, 2019b, p.17-51.

COÈDES, G. Textes d'auteurs grecs et latins relatifs à l'Extrême-Orient, depuis le IVe siècle av. J.C. Jusqu' au XIVe siècle. Paris 1910.

DAN, A. "Maes Titianos", in Gehrke, H. \& Maler, F. (ed.), Die Fragmente der Griechischen Historiker Part V, Leiden, 2013.

DAYALAN, D. "Ancient Seaports on the Eastern Coast of India: The Hub of the Maritime Silk Route Network", Acta Via Serica 4/1, 2019, p. 25-69.

DE LA VAISSIÈRE, É. "Trans-Asian trade, or the Silk Road deconstructed (antiquity, middle ages)", in L. NeAL and J. G. WilLIAMson (eds), The Cambridge History of Capitalism, Cambridge, 2014, p. 101-124.

DESROSIERS, S. and DEBAINE-FRANCFORT, C.; IDRISS, A. "Two resist-dyed cottons recently found at Karadong, Xinjiang, (3rd century AD)", in P. WALTON ROGERS, et al. (eds), The Roman Textile Industry and Its Influence. A Birthday Tribute to John Peter Wild (Textile History, special issue), Oxford, 2001, p. 48-55. 
NEARCD: Revista Eletrônica de Antiguidade 2020, Volume XII, Número II - ISSN IS8R2-8713

Núcleo de Estudas da Antiguidade - NEA

Universidade da Estada do Rio de Janeiro

ISSN 1982-8713

DESROSIERS, S. \& DEBAINE-FRANCFORT, C. “On Textile Fragments Found at Karadong, a 3rd to early 4th Century Oasis in the Taklamakan Desert (Xinjiang, China)", Textile Society of America Symposium Proceedings 958, 2016, p. 66-75.

FRANCIS, JR. P. Asia's Maritime Bead Trade 300 B.C. to the Present, Honolulu, 2002.

FULLER, D. "Old World Gobalization and Food Excanges", in K. BesCherer Metheny and M. BEAUdRY (eds), Archaeology of Food: An Encyclopedia, Lanham, 2011, p. 350-356.

EMERY, M. V. \& DUGGANA, A.; MURCHIEA, T.; STARK, R.; KLUNKA, J.; HIDERA, J.; EATONA, K.; KARPINSKIA, E.; SCHWARCZ, H. P.; POINARA, H. N.; PROWSE, T. L. Ancient Roman mitochondrial genomes and isotopes reveal relationships and geographic origins at the local and panMediterranean scales, Journal of Archaeological Science: Reports 20, 2018, p. 200-209.

EVERS, K. G. Worlds Apart Trading Together. The Organisation of Long-Distance Trade Between the Mediterranean and the Indian Ocean, Oxford, 2017.

FAUCONNIER, B. "Graeco-Roman merchants in the Indian Ocean: Revealing a multicultural trade", Topoi. Orient Occident, Supplément 11, 2012, p. 75-109.

GILG, A. \& CAST, N.; CALLIGARO, T. "Vom Karfunkelstein”, in L. WAMSER (ed.), Karfunkelstein und Seide. Neue Schätze aus Bayerns Frühzeit. Ausstellungskataloge der archäologischen Staatssammlung 37, München, 2010, p. 87-100.

GOETZ, H. “An Indian Bronze from South Arabia", Archaeology 16, 1963, p. 187-189.

GONTHIER, É. and KOSTOV, R. I.; STRACK, E. "A Han-dated 'hydra'-type nephrite scabbard slide found in Chatalka (Bulgaria): the earliest and most distant example of Chinese nephrite distribution in Europe", Arkéolog 65/4, 2014, p. 5-12.

GOSH, S. "Imprints of Hellenism in the North-west of India: Case Studies of Barikot and Charsada", Proceedings of the Indian History Congress 73, 2012, p. 169-174.

HANUS, K. "Sarmaci a północna odnoga szlaku jedwabnego", Zeszyty Naukowe Towarzystwa Doktorantów UJ Nauki Społeczne, 10, 2015, p. 25-46.

HAYES, J. Late Roman Pottery: a Catalogue of Roman Fine Wares, London, 1972.

HEINRICH, F. "Peperduur of gemeengoed? Peperconsumptie inhet Romeinse Rijk gekwantificeerd", Tijdschrift voor Mediterrane Archeologie 28/56, 2017, p. 22-31.

HILDEBRANDT, B. "Introduction: Silk on the Silk Roads. Exchange between East and West in Antiquity", in B. HILDEBRANDT and C. GILLIS (eds), Silk: Trade and Exchange along the Silk Roads between Rome and China in Antiquity, Ancient Textiles Series 19. Oxford \& Philadephia, 2017a, p. xi-xii. 
NEARCD: Revista Eletrônica de Antiguidade 2020, Volume XII, Número II - ISSN IS8R2-8713

Núcleo de Estudas da Antiguidade - NEA

Universidade da Estada do Rio de Janeiro

ISSN 1982-8713

HILDEBRANDT, B. "Silk production and trade in the Roman Empire", in B. HILDEBRANDT and C. GILLIS (eds), Silk: Trade and Exchange along the Silk Roads between Rome and China in Antiquity, Ancient Textiles Series 19. Oxford \& Philadephia, 2017b, p 34-50.

HOPPÁL, K. "The Roman Empire according to Ancient Chinese Sources", Acta Antiqua. Academiae Scientiarum Hungaricae 51, 2011, p. 263-306.

HOPPÁL, K. Contextualizing the comparative perceptions of Rome and China through written sources and archaeological data, PhD dissertation, Eötvös Loránd University, Thesis abstracts were published in Dissertationes Archaeologicae 3, 2015, p. 285-302.

HOPPÁL, K. "Ignoti facie, sed non et vellere Seres: Az oikumené legkeletibb pontjáról kialakult kép az antik források alapján", TISICUM: JÁSZ-NAGYKUN-SZOLNOK MEGYEI MÚZEUMOK ÉVKÖNYVE 26, 2018, p. 419-440.

HOPPÁL, K. "Chinese Historical Records and Sino-Roman Relations: A Critical Approach to Understand Problems on the Chinese Reception of the Roman Empire", Res Antiquitatis 1, 2019, p. 63-81.

可莱HOPPÁL, K. “Dongya gudai kua wenhua jiaoliu yanjiu: Luomadiguo de zhongtu sichou 东亚 古代跨文化交流研究：罗马帝国的中土丝绸 [Cross-Cultural Interactions in Antiquity: Chinese Silk Finds from the Roman Empire]", Kaoguxue Yanjiu 考古研究学 2020 (11) 184-200.

HOPPÁL, K. "Comparing Roman and Roman-related Artefacts in Thailand and China: Materials, Context, and Networks", Proceedings of International Conference on Maritime Exchanges and Localizations across the South China Sea, 500 BC-500 AD. Institute of Archaeology, National Cheng-Kung University, Taiwan, and the French School of Asian Studies (Ecole française d'Extrême-Orient, EFEO), November 9-11, 2018, Tainan, Taiwan (forthcoming)

HOPPÁL, K.; BELLINA, B.; DUSSUBIEUX, L. "Links between the Mediterranean world, South Asia, Southeast Asia and China from the late 1st millennium BC to the early first centuries AD", Proceedings of Alexandria the cosmopolis: a global perspective, Centre d'études alexandrines, December 2-5, 2019, Alexandria, Egypt, Études Alexandrines (forthcoming)

HORVÁTH, E. and BENDŐ, ZS. “Egy gepida kori sírból származó gránátlelet proveniencia vizsgálata. Provenance Study on a Collection of Loose Garnets from a Gepidic Period Grave in Northeast Hungary", Archeometriai Mühely 8/1, 2011, p. 17-32.

JONES, M. Fake?: The Art of Deception, Berkeley, 1990.

KILANI, M. "Contacts between Egypt and India during the Ptolemaic and Roman Periods: An Overview of the Evidence", in C. LANGER (ed.), GLOBAL EGYPTOLOGY Negotiations in the Production of Knowledges on Ancient Egypt in Global Contexts, London, 2017, p. 91-102.

KÜSTER, H. Postglaziale Vegetationsgeschichte Südbayerns Geobotanische Studien zur Prähistorischen Landschaftskunde, Berlin, 1995. 
NEARCD: Revista Eletrônica de Antiguidade 2020, Volume XII, Número II - ISSN 1982-8713

Núcleo de Estudas da Antiguidade - NEA

Universidade da Estada do Rio de Janeiro

ISSN 1982-8713

LANKTON, J. AND GRATUZE, B.; BOPEARACHCHI, O.; DUSSUBIEUX, L. "Hellenistic/Early Roman glass production at Bara, Khyber-Pakhtunkwha Province, Pakistan", Presentation at AlHV 20 Suisse 7 September 2015.

LAWTON, T. "Review of Ouzhou suocang Zhongguo qingtongqi yizhu (Chinese Bronzes: A Selection from European Collections) by Li Xueqin; Sarah Allan", Artibus Asiae 57/1.2, 1997, p. 166-169.

LI, X. 李学勤and ALLAN, S. 欧洲所藏中国青铜器遗珠 [Chinese Bronzes: A Selection from European Collections], Beijing, 1995.

LIVARDA, A. "Spicing up life in northwestern Europe: Exotic food plant imports in the Roman and medieval world", Vegetation History and Archaeobotany 20/2, 2011, p. 143-164

MAIRS, R. "Intersecting Identities in Hellenistic and Roman Egypt", in R. J. DANN and K. EXELL (eds), Egypt: Ancient Histories, Modern Archaeologies, New York, 2013, p. 163-192.

MALINOWSKI, G. "Origin of the name Seres", in G. MALINOWSKI et al. (eds), Serica - Da Qin. Studies in Archaeology, Philology and History of Sino-Western Relations (Selected Problems), Wroclaw, 2012, p. 13-26.

MCDUFF, E. "The Potentiality of Phytoliths in the Study of Roman Spices: An Investigation into the Nature of Phytoliths in Piper nigrum and Piper longum", unpublished thesis, The Faculty of the Graduate School of Arts and Sciences Brandeis University Graduate Program in Ancient Greek and Roman Studies.

MCLAUGHLIN, R. Rome and the Distant East: Trade Routes to the ancient lands of Arabia, India and China, London, 2010.

MCLAUGHLIN, R. The Roman Empire and the Indian Ocean: Rome's Dealings with the Ancient Kingdoms of India, Africa and Arabia, Barnsley, 2014.

MITSCHKE, S. \& PAETZ GEN SCHIECK, A. "Dressing the dead in the city of Rome: burial customs according to textiles", in M. CARROLL, J. P. WILD (ed.), Dressing the Dead in Classical Antiquity, Gloucestershire, 2012, p. 115-133.

PARKER, G. "Ex oriente luxuria: Indian commodities and Roman experience", Journal of the Economic and Social History of the Orient 45.1, 2002, p. 40-95.

PARKER, G. The Making of Roman India, Cambridge, 2008.

PEACOCK, D. "Stone", in D. PeAcock, L. Blue, J. Whitewright (ed.), Myos Hormos - Quseir alQadim Roman and Islamic Ports on the Red Sea. Volume 2: Finds from the excavations 19992003, Oxford, 2011, p. 121-134. 
NEARCD: Revista Eletrônica de Antiguidade 2020, Volume XII, Número II - ISSN 1982-8713

Núcleo de Estudas da Antiguidade - NEA

Universidade do Estada do Rio de Janeiro

ISSN 1982-8713

PEACOCK, D.; BLUE, L.; WHITEWRIGHT, J. (ed.), Myos Hormos - Quseir al-Qadim Roman and Islamic Ports on the Red Sea. Volume 2: Finds from the excavations 1999-2003, Oxford, 2011.

PÉRIN, P.; CALligARO, T.; VALLET, F.; POIROT, J-P.; BAGAULT, D. “Provenancing Merovingian garnets by PIXE and $\mu$-Raman spectrometry", in J. HENNING (ed.), Post-Roman Towns. Trade and Settlement in Europe and Byzantium. Vol. 1. The heirs of the Roman West, Berlin - New York, 2007, p. 69-75.

PETECH, L. "Tolomeo e i risultati di alcuni scavi archeologici sulle coste dell'Asia meridionale", Rivista di Filologia e di Istruzione Classica 78, 1950, p. 50-62.

POULAIN, D.; SCUILLER, CH.; GRATUZE, B. La parure en verre et en ambre de la nécropole mérovingienne de Saint-Laurent-des-Hommes (Dordogne), Bulletin de l'Association Française pour l'Archéologie du Verre, Association Française pour l'Archéologie du Verre, 2013, p. 72-79.

PROWSE, T.; BARTA, J.; HUNNIUS, T.; SMALL, A. "Stable isotope and mtDNA evidence for geographic origins at the site of Vagnari, South Italy", Journal of Roman Archaeology 78, 2010, p. 175-198.

REDDY, A. "Sourcing Indian ceramics in Arabia: actual imports and local imitations", Proceedings of the Seminar for Arabian Studies Vol. 45, Papers from the forty-eighth meeting of the Seminar for Arabian Studies held at the British Museum, London, 25 to 27 July 2014, 2015, p. 253-271

REDDY, A. "Archaeology of Indo-Gulf relations in the early historic period: The ceramic evidence", in H. P. RAY (ed.), Bridging the Gulf: Maritime cultural heritage of the western Indian Ocean, New Delhi, 2016, p. 53-78.

REDFERN, R.; GROCKE, D.; MILLARD, A.; RIDGEWAY, V.; JOHNSON, L.; HEFNER, J. "Going south of the river: A multidisciplinary analysis of ancestry, mobility and diet in a population from Roman Southwark, London", Journal of Archaeological Science 74, 2016, p. 11-22.

RIDGEWAY, V.; SUDDS, B.; LEARY, K. Roman Burials in Southwark: Excavations at 52-56 Lant Street and 56 Southwark, London, 2013.

RIFA-ABOU EL NIL, P. AND CALLIGARO, T. "Un atelier de taille de pierres semi-précieuses à Alexandrie", in BERETTA, M. ; BROMBLET, P. ; CALLIGARO, T. ; EMPEREUR, J-Y.; FAUCHER, T.; FROMENT, K. ; GRATUZE, B. ; MARTINETTO, P. ; MAY, R. ; NENNA, M-D. ; PICHOT, V. ; RIFA-ABOU EL NIL,P. ; VALLET, J-M. ; WALTER, P. (ed.), Chimie et Alexandrie dans l'Antiquité, Paris, 2020, p. 247-266.

ROBINSON, M. and ROWAN, E. "Roman Food Remains in Archaeology and Contents of a Roman Sewer at Herculaneum", in J. WILKINS and R. NADEAU (eds), A Companion to Food in the Ancient World, New Jersey, 2015, p. 105-115. 
NEARCD: Revista Eletrônica de Antiguidade 2020, Volume XII, Número II - ISSN 1982-8713

Núcleo de Estudas da Antiguidade - NEA

Universidade do Estada do Rio de Janeiro

ISSN 1982-8713

SÁGI, K. "Die Ausgrabungen im römischen Gräberfeld von Intereisa im Jahre 1949", in M. PÁRDUCz (ed.), Intercisa 1. Dunapentele - Sztálinváros története a római korban - Archaeologia Hungarica, Series nova 33, Budapest, 1954, p. 61-123.

SALOMON, R. "Epigraphic Remains of Indian Traders in Egypt", Journal of the American Oriental Society 111/4, 1991, p. 731-736

SCHENK, H. "Role of ceramics in the Indian Ocean maritime trade during the Early Historical Period", in S. TRIPATI (ed.), Maritime contacts of the past: Deciphering connections amongst communities, New Delhi, 2015, p143-181.

SCHENK, H. and PAVAN, A. "Crossing the Indian Ocean before the Periplus: a comparison of pottery assemblages at the sites of Sumhuram (Oman) and Tissamaharama (Sri Lanka)", Arabian Archaeology and Epigraphy 23/2, 2012, p. 191-202.

SCHNEIDER, R. Bunte Barbaren. Orientalenstatuen aus farbigem Marmor in der römischen Repräsentationskunst, Worms, 1986.

SCHWINDEN, L. "Handel mit Pfeffer und anderen Gewürzen im römischen Trier", Kurtrierisches Jahrbuch 23, 1983, p. 20-26.

SELAND, E. "Ports, Ptolemy, Periplus and Poetry-Romans in Tamil South India and the Bay of Bengal", in E. H. SELAND (ed.), The Indian Ocean in the Ancient Period: definite places, translocal exchange, BAR International Series 1593, Oxford, 2007, p. 69-82.

SIDEBOTHAM, S. E. Berenike and the Ancient Maritime Spice Route, California, 2011.

SIMONENKO, A. "Chinese and Eas Asian Elements in Sarmatian Culture of the North Pontic Region", Silk Road Art and Archaeology 7, 2001, p. 53-72.

SMALL, A. and SMALL, C.; PROWSE, T. "Excavation in the roman cemetery at Vagnari in the territory of Gravina in Puglia" Papers of the British School at Rome 78, 2007, p. 123-229.

STAUFFER, A. "Textiles from Palmyra: Local Production and the Import and Imitation of Chinese Silk Weavings", Annales Archéologiques Arabes Syriennes 42, 1996, p. 425-430.

STAUfFER, A.; COLINET, A.; AL-AS'AD, K. Die Textilien aus Palmyra. Neue und alte Funde, Mainz am Rhein, 2000.

STRAUCH, I. (ed.), Foreign Sailors on Socotra, Bremen, 2012.

THEN-OBŁUSKA, J. "Bead Trade in Roman Ports: A View from the Red Sea Port of Marsa Nakari", in D. J. DE FALCO (ed.), Stories of Globalisation: The Red Sea and the Persian Gulf from Late Prehistory to Early Modernity Selected Papers of Red Sea Project VII, Leiden, 2018, p. 264-280. 
NEARCD: Revista Eletrônica de Antiguidade 2020, Volume XII, Número II - ISSN 1982-8713

Núcleo de Estudas da Antiguidade - NEA

Universidade do Estada do Rio de Janeiro

ISSN 1982-8713

TOMBER, R. "Indo-Roman trade: the ceramic evidence from Egypt", Antiquity 74/285, 2000, p. 624-631.

TOMBER, R. "Indian Fine Wares from the Red Sea Coast of Egypt", Man and Environment 27/1, 2002, p. 26-31.

TREISTER, М. МЮ ТРЕЙстEP “Китайские «импорты» в погребениях кочевников Восточной Европы во второй половине I тыс. до н. э. - первых веках нашей эры. Chinese 'Imports' in the Burials of the Nomads of Eastern Europe in the Second Half of the 1st Millennium BC - First Centuries AD", Stratum plus Археология и культурная антропология 4, 2018, р. 153-200.

TROUSDALE, W. The Long Sword and Scabbard Slide in Asia, Smithsonian Contribution to Anthropology 17, Washington, 1975.

TUPIKOVA, I.; SCHEMMEL, M.; DE GEUS, K. Travelling along the Silk Road: A new interpretation of Ptolemy's coordinates, Berlin, 2014.

VAN DER VEEN, M. Consumption, Trade and Innovation: exploring the botanical Remains from the Roman and Islamic ports at Quseir al-Qadim, Egypt, Frankfurt am Main, 2011.

VON LIEVEN, A. "Trade Contacts and Cultural Exchange between Egypt and India in the Ptolemaic and Roman Period", in N. JASPERT and S. KOLDITZ (eds), Entre mers-Outre-mer: Spaces, Modes and Agents of Indo-Mediterranean Connectivity, Heidelberg, 2018, 61-76.

VESSBERG, B. "Un bronze du style Houai decouvert it Rome", Bull. Museum Far Eastern Antiquities (Stockholm) 9, 1937, p. 127-31.

VON FALKENHAUSEN, L. "Die Seiden mit Chinesischen Inschriften", in A. SCHMIDT-Colinet, A. StAUfFER, K. Al-As'AD (Hrsg), Die Textilien aus Palmyra. Neue und alte Funde, Mainz am Rhein, 2000, p. 58-82.

WERNER, J. “Chinesischer Schwerttragbügel der Han-Zeit aus einem thrakischen Häuptlingsgrab von Čatalka (Bulgarien)", Germania 72/1, 1994, p. 269-282

WHITEHOUSE, D. “Chinese Porcelain in Medieval Europe”, Medieval Archaeology, 16/1, 1972, p. $63-78$

WILD, J. P. and WILD, F. "Rome and India: early Indian cotton textiles from Bereinke, Red Sea Coast if Egypt", in R. BARNE (ed.), Textiles in Indian Ocean Societies, London-New York, 2005, p. 11-26.

WILD, J. P. and WILD, F. "Through Roman Eyes: Cotton Textiles from Early Historic India", in S. BERGERBRANT and S. H. Foss $\varnothing \mathrm{Y}$ (eds), A Stitch in Time: Essays in Honour of Lise Bender Jørgensen, Gothenburg, 2014, p. 209-236 
NEARCD: Revista Eletrônica de Antiguidade 2020, Volume XII, Número II - ISSN 1982-8713

Núcleo de Estudas da Antiguidade - NEA

Universidade do Estada do Rio de Janeiro

ISSN 1982-8713

YU, T. "China and the Ancient Mediterranean World. A Survey of Ancient Chinese Sources", SinoPlatonic Papers 242, 2013, p. 1-268.

ZHAO, F. "Domestic, wild or unraveled? A study on tabby, taqueté and jin with spun silk from Yingpan, Xinjiang, third-fourth centuries", in B. HILDEBRANDT and C. GILLIs (eds), Silk: Trade and Exchange along the Silk Roads between Rome and China in Antiquity, Ancient Textiles Series 19. Oxford \& Philadephia, 2017, p, 95-103.

ZHAO, H.; Q. LI, S. LIU, L. LI, F. GAN, "In situ analysis of stratified glass eye beads from the tomb of Marquis $Y i$ of the Zeng State in Hubei Province, China using XRF and micro-Raman spectrometry", X-Ray Spectrometry 43(6), 2014, p. 316-324.

ŻUCHOWSKA, M. "From China to Palmyra. The value of silk", Światowit 11 (52)/A, 2013, p. 133154.

ŻUCHOWSKA, M. "Grape Picking" Silk from Palmyra: a Han Dynasty Chinese Textile with a Hellenistic Decoration Motif", Światowit 12 (53)/A, 2015, p. 143-162.

ŻUCHOWSKA, M. "Transferring Patterns along the Silk Road: Vine and Grape Motifs on Chinese Silks in the 1st Millennium AD", The Artistic Traditions of Non-European Cultures 4, 2016, p. 6780. 